\title{
The Empirical Study on Financing Constraints of Small and Medium-sized Enterprises in \\ China
}

\author{
${ }^{1}$ Jianing Li, ${ }^{2}$ Yinghua Li, ${ }^{3}$ Fengmei Kou \\ ${ }^{1,2,3}$ Lanzhou City College, Lanzhou, Gansu, 730070, China
}

\begin{abstract}
The dynamism of a country's economy depends on the status of small and medium-sized enterprises, especially small micro-enterprises at a large extent. After 30 years of reform and opening up, the rapid development of Chinese small and medium enterprises has grown into an important force in the development of Chinese national economy. However, the financing constraints of SMEs in China have seriously hindered and restricted the survival and development of small and medium enterprises in China. The financing of small and medium-sized enterprises has been the primary problem for the rapid development and further transformation and upgrading of Chinese small and medium-sized enterprises.

Keywords: empirical study, financing constraints, small and medium-sized enterprises
\end{abstract}

\section{Introduction}

With the increasing awareness and concern of the role of SMEs in the world government and the community, the development of SMEs in the process of financing difficulties generally faced by the attention of countries in the world. The financing dilemma of small and medium-sized enterprises in our country is increasingly becoming the shackles of the development of small and mediumsized enterprises, which greatly affect the vitality of the most dynamic part of the economic system of small and medium-sized enterprises. It is precisely because of this, the plight of SMEs financing is increasingly being the attention of our theoretical circles. 


\section{The concept of financing}

Financing, that is, financing. In general, financing refers to the flow of funds between different owners of the two-way interactive process, which is financing a broad concept. Narrow financing refers to the raising of funds, that is, through a variety of ways and means of access to funds in the process. The main research scope of this paper is financing in the narrow sense, that is, the fund raising of small and medium-sized enterprises. Capital is a scarce resource, no one enterprise cannot fully use the free funds to meet the needs of production and development, SME financing is actually a social resource allocation process. According to the basic principles of market economy, allocating limited financial resources to enterprises or sectors with high output efficiency or economic development will not only improve the efficiency of social resource allocation, but also stimulate inefficient departments to improve their efficiency.

\section{The main reasons for SME financing constraints}

\subsection{Its own factors}

From the ability of small and medium enterprises to resist risks, the majority of SMEs lack of leading industries, there is no brand, its business development goals are not clear, blindly low-level low-efficiency repetitive production and management, is bound to bear the brunt of the financial crisis struck And the ability to resist risks is self-evident. In addition, the majority of small and medium-sized small-scale, relatively poor strength, the lack of quality assets can be used for mortgage - policy tightening, not timely access to financial institutions from banks and other necessary financial intermediation, which also determines their own risk of small and medium enterprises of the poor.

\subsection{The capital market}

Although China's capital market has gradually improved and perfected after 30 years of development, China's capital market is still at the initial stage compared with the developed market economy countries. In order to control the financial risk of capital market, China has been in recent years, strict control of securities trading within the scope of the stock exchange, although there are OTC, but its size is relatively small. Therefore, China's capital market structure of a single, almost only a level of securities products. This single structure of the capital market cannot make the capital market mechanism play a large role and it cannot reasonably guide the flow of capital market funds, is not conducive to reducing the overall risk of capital market system. 


\subsection{Financial system}

From the perspective of major commercial banks, due to the existence of serious information asymmetry in the SME financing market, China's major commercial banks have established corresponding risk control to avoid the adverse selection and moral hazard caused by this And risk-constrained mechanisms. Most large commercial banks have the right to approve loans to the head office or provincial branches, local branches in many cases, the only deposit; due to the existence of high deposit and lending interest rates, large commercial banks in China is biased And the large-scale enterprises, especially large state-owned enterprises; adhere to the key industries, key enterprises, key areas, key customers "fourfold" principle, mainly for high security industries and large enterprises to provide loans.

\section{The empirical research of SME financing constraints}

The sample data used in this article all come from the Guotai Junan Shanghai and Shenzhen Stock Exchange listed on the SME board and the main board of listed companies. Descriptive statistical results of the sample As shown in Table 1, the average proportion of bank borrowings in 1328 sample companies is $47.91 \%$ of the 522 SME listed companies. Among them, the short-term loans and bank loans on behalf of the proportion of the two indicators of the minimum value of 0 . Among the 1328 sample enterprises, 218 short-term borrowings were 0; shortterm borrowings were 97.2 billion RMB, with an average value of 1.21 billion RMB, with a median value of 271 million RMB and a standard deviation of 4.27 billion RMB. There were 77 accounts payable between 0 and 10 million, of which the maximum was 209 billion RMB, with an average of 1.52 billion RMB, with a median value of 234 million RMB and a standard deviation of 9.57 billion RMB. The proportion of bank loans in the $0 \sim 30 \%$ of 615 , of which the maximum value of $97.99 \%$, mean $48.01 \%$, the median is $47.93 \%$, the standard deviation of $26.54 \%$.

Table 1. Sample enterprise variable descriptive statistics

\begin{tabular}{|l|l|l|l|l|l|}
\hline & Mean & Median & Max & Min & SD \\
\hline $\begin{array}{l}\text { Accounts } \\
\text { Receivable }\end{array}$ & $7.46 \mathrm{E}+08$ & $1.35 \mathrm{E}+08$ & $8.15 \mathrm{E}+10$ & 0 & $3.83 \mathrm{E}+09 \sim$ \\
\hline $\begin{array}{l}\text { Current } \\
\text { Liabilities }\end{array}$ & $5.89 \mathrm{E}+09$ & $1.56 \mathrm{E}+09$ & 477331.1 & 0 & $2.19 \mathrm{E}+10 \sim$ \\
\hline Fixed Assets & $3.98 \mathrm{E}+09$ & $5.68 \mathrm{E}+08$ & $5.41 \mathrm{E}+11$ & 0 & $2.30 \mathrm{E}+10 \sim$ \\
\hline Total Assets & $1.29 \mathrm{E}+10$ & $3.16 \mathrm{E}+09$ & $1.66 \mathrm{E}+12$ & 477331.1 & $6.16 \mathrm{E}+10$ \\
\hline $\begin{array}{l}\text { Short-Term } \\
\text { Loan }\end{array}$ & $1.21 \mathrm{E}+09$ & $2.71 \mathrm{E}+08$ & $9.72 \mathrm{E}+10$ & 0 & $4.27 \mathrm{E}+09$ \\
\hline $\begin{array}{l}\text { Payable } \\
\text { Accounts }\end{array}$ & $1.52 \mathrm{E}+09$ & $2.34 \mathrm{E}+08$ & $2.09 \mathrm{E}+11$ & 0 & $9.57 \mathrm{E}+09$ \\
\hline $\begin{array}{l}\text { Current } \\
\text { Liabilities }\end{array}$ & $5.36 \mathrm{E}+09$ & $1.24 \mathrm{E}+09$ & $4.30 \mathrm{E}+11$ & 100000 & $2.22 \mathrm{E}+10$ \\
\hline
\end{tabular}




\begin{tabular}{|l|l|l|l|l|l|}
\hline Liabilities & $7.65 \mathrm{E}+09$ & $1.58 \mathrm{E}+09$ & $6.46 \mathrm{E}+11$ & 100000 & $3.18 \mathrm{E}+10$ \\
\hline $\begin{array}{l}\text { Other } \\
\text { Payables }\end{array}$ & $5.15 \mathrm{E}+08$ & $1.05 \mathrm{E}+08$ & $5.49 \mathrm{E}+10$ & 35437.73 & $2.21 \mathrm{E}+09$ \\
\hline $\begin{array}{l}\text { Proportion of } \\
\text { Bank Loans }\end{array}$ & 0.479051 & 0.489939 & 0.982785 & 0 & 0.285468 \\
\hline
\end{tabular}

\section{Suggestions on solving the financing constraints of Chinese small and medium-sized enterprises}

\subsection{Establish the policy financial institutions providing specialized services for SMEs}

To solve the difficult problem of small and medium-sized enterprises loans, the state-owned commercial banks rely solely on the credit channel is impossible to achieve, an effective way is to set up specifically for small and medium-sized policy banks or policy financial institutions. Policy-oriented financial institutions are set up by the government and are not aimed at profit-making or profitmaximization. In some professional or developmental fields, special financial instruments are used to implement and cooperate directly with national economic and social policies. Small and medium-sized policy banks can be jointly financed by the central government and local governments, state-owned or other jointstock commercial banks.

\subsection{Promote financial innovation and meet the diverse needs of SMEs}

With the development of commodity economy and the progress of science and technology, financial innovation has become an objective requirement. Financial innovation is a "win-win" option for investors and financiers. First of all, to improve the level of innovation, to carry out various forms of financial innovation activities, is conducive to the implementation of SME customers' differentiated operation, to provide "tailored" credit services to solve the financing needs of SMEs at different stages of development. For financial institutions, to obtain the existing financial system and financial instruments cannot be achieved by the potential profits, to achieve win-win situation between banks. Second, to promote domestic and foreign financial industry with financial innovation, financial and financial intelligence can be combined. Some financial products, such as UNPROFOR loan business, Loan Recycling business, bill financing business, pawn financing, accounts receivable mortgages and warehouse receipts pledged loans, provide more lenient and more open choice for SME financing.

\subsection{Develop and improve the SME credit guarantee system}

Credit guarantee is to resolve the two sides of the transaction information asymmetry arising from the credit intermediary activities. In the credit guarantee, 
the guarantor (credit guarantee institutions) the ability to perform is very reassuring, even if the creditor to the debtor can perform without adequate information, but in general, there is a guarantee of credit guarantee institutions, financial institutions will increase Loans to the release of confidence. As a bridge between the financial sector and small and medium-sized enterprises, credit guarantee institutions play an important role in facilitating the financing of small and medium-sized enterprises, diversifying the credit risk of financial institutions and creating corporate credit. However, there are still many problems in China's SME credit guarantee institutions, such as lack of standardized guarantee institutions laws and regulations, single source of guarantee funds, lack of capital compensation mechanism, lack of credit and so on.

\section{Conclusion}

Chinese small and medium enterprises are facing serious financial difficulties. Financing difficulties is becoming an important factor in the development of small and medium enterprises in China. However, what is the real situation of SME financing in China, what are the factors influencing SME financing decision-making, and what causes the current financing dilemma, for our series of problems, our scholars have not given a systematic and accurate answer. Therefore, finding out the answers to these questions to promote the development of small and medium enterprises in China has become an urgent task.

\section{Acknowledgements}

Lanzhou Science and Technology Bureau Soft Science and Technology Projects: The small and medium-sized enterprise financing model innovation research (2014-1-78)

Gansu Provincial Science and Technology Program Soft Science Projects: Gansu Province establish enterprise-led industrial technology research and innovation institutional mechanisms (1604ZCRA004)

\section{References}

[1] Wu Xiaofei. The Restrictive Factors of Small and Medium - sized Enterprises' Financing. Finance, 55(12), pp.68-70, 2011

[2] Xie Ruliang. The International Experiences of Policy Finance to Support the Development of Small and Medium - sized Enterprises, Banker. 8 (5), pp.87- 91, 2013

[3] Lin Yifu. The Development and the Financing of Small and Medium - sized Enterprises, Economic Research, 12(10), pp. 18- 20, 2012

[4] Zhang Jie. The Financial Predicament and Financing Order of Private Economy. Economic Research, 9(6), pp.58- 61, 2011

[5] Liu Haiying. The Financing Structure and Influencing Factors of Small and Medium - sized Enterprises, Journal of Theoretical, 8(4), pp.85-87, 2014 